\title{
A Study of Relationships between L1 Pragmatic Transfer and L2 Proficiency
}

\author{
Jiemin Bu \\ Foreign Languages School, Zhejiang Guangsha College of Applied Construction \\ Dongyang, Zhejiang 322100, China \\ E-mail: bujiemin@126.com
}

Received: September 6, 2011

Accepted: October 28, 2011

Published: January 1, 2012

doi:10.5539/elt.v5n1p32

URL: http://dx.doi.org/10.5539/elt.v5n1p32

\begin{abstract}
Studies in interlanguage pragmatics have shown that L2 learners' proficiency has an influence on the occurrences of L1 pragmatic transfer. However, questions remain whether the relationship between L1 pragmatic transfer and L2 proficiency is positive or negative. This paper is designed to study L1 pragmatic transfer in requests made by Chinese learners of English at low L2 proficiency level and at high L2 proficiency level and how L1 pragmatic transfer is related to their L2 proficiency. Ten low proficiency learners of English, ten high proficiency learners of English, ten native speakers of English and ten native speakers of Chinese participate in this study. Requests are collected by means of a discourse completion test questionnaire and are analysed in terms of requestive semantic formulas based on the taxonomy of request strategies, internal modifiers and external modifiers. The research results reveal that L1 pragmatic transfer decreases with the increase of L2 proficiency such as learners' use of direct strategies, lexical and phrasal downgraders, imperatives and grounder and no clear relationship is found between L1 pragmatic transfer and L2 proficiency in terms of the other request strategies, internal modifiers and external modifiers. These results provide partial support to negative correlation hypothesis - high proficiency L2 learners are less likely to transfer their native language pragmatic norms since they have enough control over L2.
\end{abstract}

Keywords: Requestive semantic formula, L1 pragmatic transfer, L2 proficiency, Chinese learner of English

\section{Introduction}

Pragmatic transfer is a research branch of interlanguage pragmatics, which can be understood as the influence exerted by learners' pragmatic knowledge of languages and cultures other than second language on their comprehension, production and learning of second language pragmatic information (Kasper, 1992: 207). Many studies show that although learners may have learned the target language grammar and the target language form, they are not necessarily able to understand the social and cultural rules which constrain the target language use. In their communication with native speakers of the target language, learners tend to transfer their native social and cultural norms into the target language, produce inappropriate linguistic behaviours, and lead to pragmatic failure. This phenomenon is referred to as L1 pragmatic transfer. L1 Pragmatic transfer can be caused by many factors, including learners' L2 proficiency (Takahashi \& Beebe, 1987; Olshtain \& Cohen, 1989; Takahashi, 1996). Relative little research literature has been found on the relationship between L1 pragmatic transfer and L2 proficiency for Chinese learners of English, and several existing studies have shown inconsistent research conclusions. This paper intends to study the relationship between L1 pragmatic transfer and L2 proficiency by investigating request strategies used by high and low proficiency levels of Chinese learners of English.

\section{Research Questions}

This present study aims to answer the following three questions:

(1) Is there L1 pragmatic transfer in frequency and content of semantic formulas used in request strategies by Chinese EFL learners at different L2 proficiency levels?

(2) Is there any difference in L1 pragmatic transfer in frequency and content of semantic formulas used in request strategies by Chinese EFL learners at different L2 proficiency levels?

(3) How is L1 pragmatic transfer correlated with learners' L2 proficiency? 


\section{Literature Review}

The relationship between L1 pragmatic transfer and L2 proficiency has been a controversial problem. There are three different views on it. (1) L1 pragmatic transfer is positively correlated with learners' L2 proficiency. (2) L1 pragmatic transfer is negatively correlated with learners' L2 proficiency. (3) L1 pragmatic transfer is not apparently correlated with learners' L2 proficiency.

\subsection{Previous Research on the Positive Correlation Hypothesis}

In their study of refusals of Japanese learners of English at different proficiency levels, Takahashi \& Beebe(1987) propose the positive correlation hypothesis that L2 proficiency is positively correlated with L1 pragmatic transfer. According to their hypothesis, L2 learners at low language proficiency level are less likely to show L1 pragmatic transfer in L2 production than L2 learners at high language proficiency level because low proficiency L2 learners do not have necessary linguistic knowledge to transfer pragmatic knowledge of their native language. High proficiency L2 learners are more likely to display sociocultural norms of their native language in L2 production because they have control over the target language. Takahashi \& Beebe (1987) also hypothesize that there would be more L1 pragmatic transfer in English as foreign language context than in English as second language context.

Takahashi and Beebe (1987) also argue that content and tone of ESL learners' refusals provide more convincing evidence for their positive correlation hypothesis. High proficiency ESL learners appear to possess more language expressions than low proficiency ESL learners and they have more ability to adjust the directness of their refusals according to the different situations than low proficiency ESL learners. Low proficiency ESL learners use more direct and less formal language expressions more frequently than high proficiency ESL learners because low proficiency ESL learners are able only to use simpler and more direct expressions. The refusals employed by high proficiency ESL learners often contain such intensifiers as "really", "terribly" and "extremely" and therefore reflect their ability to adjust the directness of their refusals. Their mastery of various language expressions in the target language allows them able to transfer the sociocultural norms of Japanese into English.

Blum-kulla (1982) support the hypothesis that learners' insufficient L2 knowledge prevents L1 pragmatic transfer. They investigate request strategies used by Canadian English-speaking learners of Hebrew. Their research provides evidence of transfer of social norms of the native language into the target language because they tend to choose less direct request strategies than those often used by native Hebrew speakers. It also indicates that learners do not transfer indirect request strategies into Hebrew because they lack the complicated target language knowledge to express indirect request strategies in Hebrew, and they rely on the simplification of request strategies in the target language.

Olshtain \& Cohen (1989) indicate that Hebrew learners of English fail to transfer apology strategies of the native language and modifying devices into the target language because they have not had a good command of the complex target language knowledge. They say "it often happens that nonnative speakers are aware of sociolinguistic need to apology, yet because their competence is limited, they use erroneous language forms and produce speech acts that sound deviant or even create communication failure." However neither Blum-Kulla nor Olshtain \& Cohen study their learners' L1 pragmatic transfer at different L2 proficiencies.

Several other studies also show that L2 learners fail to express themselves effectively in the target language because they have the limited target language proficiency. Scarcella \& Brunk (1981) report that Arbic learners of English often use less variety of politeness strategies in their target language request. Scarcella (1983) reports that Spanish learners of English use fewer consecutive back channel cues when they communicate in the target language than when they communicate in the native language. These findings imply that even if L2 learners want to transfer pragmatic knowledge of their native language, they will not be able to do so in that their limited L2 proficiency prevents them from expressing sociocultural norms of their native language through the appropriate target language forms.

\subsection{Previous Research on Non-Positive Correlation Hypothesis}

Trosborg (1987) makes a comparative study of apology strategies employed by the different proficient groups of Danish learners of English using role-play. There are twelve native Danish speakers, twelve native English speakers and twelve Danish learners of English in each group of low level learners, intermediate level learners and advanced level learners. She has not found the apparent proficient effect on L1 pragmatic transfer according to frequencies of apology strategies used by the three levels of learners, compared with those of the Danish native speakers and those of the native English speakers.

Takahashi \& Dufon (1989) examine the relationship between L1 pragmatic transfer and learners' L2 proficiency. They find the results contradicting the positive correlation hypothesis. In their study, there are nine female Japanese 
learners of English living in Honolulu. According to their TOEFL scores, they are at three different language levels: advanced learners, intermediate learners and beginning learners. Takahashi \& Dufon investigate whether Japanese learners of English transfer their indirect request strategies into English in their role-plays. They hypothesize that beginning learners would be more indirect in their target language request realization pattern than advanced learners because beginning learners would transfer the sociocultural norm of Japanese native speakers' preference for indirectness in performance of their requesting speech act.

Maeshiba etal. (1996) also test the positive correlation hypothesis. They conduct a study of apology strategies used by Japanese learners of English. Based on their TOEFL scores, Japanese learners of English are divided into two groups: thirty advanced learners and thirty intermediate learners. The findings of this study are that intermediate learners transfer indirect apology strategies of their native language into their apologies in English .They also find that advanced learners display explicit apologies, intensifiers and sympathy in their apologies in English as native English speakers do.

Takahashi (1996) studies the transferability of five Japanese indirect request strategies into English, and how the transferability interacts with the degree of imposition involved in a request situation and with learners' L2 proficiency. There are one hundred forty two Japanese learners of English involved in this study who are freshmen and sophomore in a Japanese university. Their English proficiency is measured by Form One of Secondary Level English Proficiency Test. Takahashi argues that learners' transferability is influenced by the different degree of imposition indicated by its communicative goal. She finds neither a positive correlation nor a negative correlation between L1 pragmatic transfer and L2 proficiency because both low proficiency learners and high proficiency learners rely equally on their native language request rules when they carry out their requests in the target language.

\section{Methodology}

\subsection{Subjects}

Forty subjects in the present study include ten Chinese low proficiency learners of English, ten Chinese high proficiency learners of English, ten native English speakers, and ten native Chinese speakers. They form four groups, i.e the Chinese low proficiency learner of English group, the Chinese high proficiency learner of English group, the native English group, and the native Chinese group. Each group contains ten subjects. The subjects are all non-English major undergraduate students, the relative social power in each group is equal, and the social distance is neutral. The subjects in the Chinese low proficiency learner of English group are first-year undergraduate students with their English score from 90 to 100 in entrance college examination, and the subjects in the Chinese high proficiency learner of English group are third-year undergraduate students with their CET-6 score over 450, and the subjects in the native Chinese group are first-year undergraduate students with their English score lower than 75 in entrance college examination. All subjects give consent for their data to be used for this research purpose by signing the consent form prior to data collection.

\subsection{Instrument}

The instrument used in this study is a discourse completion test questionnaire. The questionnaire has an initial introductory section, where the subjects are asked to provide a certain amount of background information, such as their name, their gender, their age, their grade and their field of specialization. Following this, There are ten situations (see Appendix 1). These situations are used to elicit production of requests.

The situations are generated through discussion with native English speakers and native Chinese speakers. Modifications are frequently made in the situation designing process in order for the situations to be more plausible in both Chinese culture and English culture. It is important that the situations in the discourse completion test questionnaire should be equivalent cross-culturally. Therefore, in this study, after the situations are designed, the researcher consults several native Chinese speakers and several native English speakers to confirm whether these situations are feasible in their daily life. And then, these situations are further modified to achieve cultural equivalence. In order to avoid the native Chinese speakers' misunderstanding of what they are required to do in the discourse completion test questionnaire and their being influenced from English language they have learned, the questionnaire given to them are translated into Chinese (see Appendix 2). In order to achieve the equivalence in the questionnaire translation, back translation technique is employed in order to reduce threat to the reliability and validity of the research.

\subsection{Coding Scheme}

The unit of analysis for requests in the discourse completion test questionnaire is the utterance or sequence of utterances supplied by the subjects in completing the questionnaire provided that it contains or realizes a realization of requesting speech act. Such utterances or sequences of utterances are called requestive semantic formulas. 
The coding scheme of requestive semantic formulas in this study is mainly based on the coding scheme of request from CCSARP developed by Blum-Kulka et al (1989). The requestive semantic formulas can be divided into three categories: request strategies, internal modifiers and external modifiers. Request strategies are semantic formulas for performing requesting speech act. Internal modifiers are syntactic downgraders and lexical/phrasal downgraders which mitigate the illocutionary force of a request, and upgraders which enhance it (Blum-Kulka, 1989). External modifiers may provide the reason for the following request, soften it, or are part of the speaker's strategy to control over the hearer's actions (Aijmer, 1996: 170). The coding scheme of request strategies, internal modifiers and external modifiers in this study are shown in Table 1, Table 2 and Table 3.

\subsection{Data Analysis}

Before the data collection, the instructions have been given to all the subjects that the Chinese low proficiency learner of English group, the Chinese high proficiency learner of English group and the native English group are required to complete their questionnaires in English and the native Chinese group is required to complete its questionnaires in Chinese in order to make sure that questionnaires completed by the Chinese low proficiency learner of English group and the Chinese high proficiency learner of English group represent Chinese EFL learners' pragmatic features, that questionnaires completed by the native English group reflect native English speakers' pragmatic features, and that questionnaires completed by the native Chinese group show native Chinese speakers' pragmatic characteristics. These requirements will make the data from the respective groups truly reflect their respective subjects' culture-specific pragmatic phenomena.

This study involves a questionnaire survey of forty subjects. Ten questionnaires of the English version are administered to ten Chinese low proficiency learner of English subjects, ten questionnaires of the English version are provided to ten Chinese high proficiency learner of English subjects, ten questionnaires of the English version are presented to ten native English subjects, and ten questionnaires of the Chinese version are given to ten native Chinese subjects. Forty distributed questionnaires are returned. The number of requests is one hundred requests in English collected from the Chinese low proficiency learner of English group, one hundred requests in English collected from the Chinese high proficiency learner of English group, one hundred requests in English collected from the native English group, and one hundred requests in Chinese collected from the native Chinese group. One hundred requests in Chinese collected from the native Chinese group are translated into English word for word. Therefore one hundred requests in English from the Chinese low proficiency learner of English group, one hundred requests in English from the Chinese high proficiency learner of English group, one hundred requests in English from the native English group and one hundred requests in English version translated literally from the completed Chinese questionnaires of the native Chinese group are used for statistical analysis.

Data analysis of this study is mainly adapted from that of Jihyun Kwon (2003) in the study of pragmatic transfer involving refusals by Korean learners of English. After the forty questionnaires are collected, according to the coding scheme of Table 1, Table 2 and Table 3, the data are coded and analysed by SPPS.11. The number of each semantic formula in each group is counted and the percentage of a semantic formula in each group in relation to the total number of semantic formulas in that group is calculated.

\section{Results and Discussion}

\subsection{Frequency of Request Strategies}

The total number of each type of request strategies and each sub-type of request strategies for each group are presented in Table 4 and Table 5 in terms of frequency and percentage. Chi-square test shows that four groups have significant differences in the choice of request strategies at the significance level $\left(X^{2}=94.863, P=.000\right)$. As Table 4 indicates, conventionally indirect strategies are most frequently used by all groups. This finding is consistent with that of Blum-Kulka et al (1989), indicating the universality of conventionally indirect strategies of request behaviours. The employment of direct strategies comes after conventionally indirect strategies. Indirect strategies (hints) are least frequently used by all groups.

An overall tendency of direct strategies is shown in Table 4. The use of direct strategies shows the decreasing tendency with the increase of learners' L2 proficiency. The Chinese high proficiency learner of English group uses fewer direct strategies than the Chinese low proficiency learner of English group. Table 4 also indicates that the use of conventionally indirect strategies increases with learners' L2 proficiency and shows development tendency toward native English speakers. With respect to the use of non-conventionally indirect strategies, all groups employ much fewer them compared with direct strategies and conventionally indirect strategies, as shown in Table 4. Despite the general shortage of non-conventionally indirect strategies, the two learner groups use fewer non-conventionally indirect strategies than the native English group and the native Chinese group. All groups seldom employ indirect strategies because request behaviours require relatively less need of indirect strategies. The 
Chinese low proficiency learner of English group, the native English group and the native Chinese group display opting out more frequently than the Chinese high proficiency learner of English group. The Chinese low proficiency learner of English group opts out of any situation in which linguistic devices fail them, and the native English group and the native Chinese group opt out of the situations which involve large imposition and are thus face-threatening.

Additional information on the use of sub-types of request strategies in Table 5 is given to shed light on learners' behaviours. Direct strategies are realized by five sub-strategies: imperatives, want statements, performatives, hedged performatives and obligation statements. Among these five sub-strategies, imperatives and want statements are used most frequently by all the groups while performatives, hedged performatives and obligation statements are less employed. The employment of imperatives decreases with the increase of L2 proficiency, the Chinese low proficiency learner of English group produces significantly more imperatives than both the Chinese high proficiency learner of English group and the native English group. Conventionally indirect strategies are realized by two sub-strategies: suggestory formula and query preparatory. It is found that unlike the native Chinese group who uses suggestory formula most frequently among the four groups, all the learner groups rely on preparatory, and the native English group prefers to use such modal verbs as Could and would.

\subsection{Frequency of Internal Modifiers}

An overall tendency of internal modifiers employed by each group and a distribution of each type of internal modifiers within each group are shown in Table 6 and Table 7. Chi-square test indicates that four groups have significant differences in the choice of internal modifiers at the significance level $\left(X^{2=} 685.936, P=.000\right.$. $)$ As is shown in Table 6, upgraders are least used by all groups. The Chinese high proficiency learner of English group employs significantly more syntactic downgraders than the Chinese low proficiency learner of English group and use significantly fewer syntactic downgraders than the native English group, whereas the Chinese high proficiency learner of English group employs significantly fewer lexical and phrasal downgraders than the Chinese low proficiency learner of English group and use significantly more lexical and phrasal downgraders than the native English group. It seems that on the whole the Chinese high proficiency learner of English group performs differently from the Chinese low proficiency learner of English group and shows much development tendency toward native English speakers' request performance in terms of English grammar and vocabulary.

From Table 7 we can see frequencies and percentages of each type of internal modifiers within each group. With respect to syntactic downgraders, the learner groups and the native English group rarely use English negations whereas the native Chinese group makes extensive use of Chinese negations. The Chinese high proficiency learner of English group uses more past tense than the Chinese low proficiency learner of English group and the native English group. The learner groups at all proficiency levels employ much fewer embedded conditional structures than the native English group. As for lexical and phrasal downgraders, the Chinese high proficiency learner of English group uses considerably fewer hedges than the Chinese low proficiency learner of English group and resembles the performance of the native English group. But it seems difficult for the Chinese high proficiency learner of English group to employ a variety of English hedges in making requests. As subjectivizers are concerned, the Chinese high proficiency learner of English group employs fewer subjectivizers than the Chinese low proficiency learner of English group and more subjectivizers than the native English group. The number of upgraders is too small to be statistically analysed. Despite this, the learner groups employ fewer upgraders than both the native English group and the native Chinese group.

\subsection{Frequency of External Modifiers}

Frequencies and percentages of external modifiers employed by each group are shown in Table 8. The use of seven major types of external modifiers is analysed in the present study: preparator, ground, apology, gratitude, offer, promise and others. The category of others includes a range of less frequently used external modifiers, such as empathy, moralizing, confirmation et.ac. Table 8 shows that the external modifiers used by the learner groups and the native groups are similar in both frequency and type with a decreasing order of: grounder, gratitude, offer, apology, promise, preparator. Grounder and gratitude are preferred by all the groups. With respect to specific type of external modifiers, it is found that the native English group uses fewer grounders than the Chinese low proficiency learner of English group, the Chinese high proficiency learner of English group and the native Chinese group because the native English group makes a request in a direct way or as what it should be and the learner groups tend to follow the native Chinese patterns of grounder by providing more responsibility-oriented and more subjective reasons when they make a request.

\subsection{Effect of L1 Influence on L2 Requests}

With respect to request strategies, evidence of L1 influence is found in type and frequency of specific semantic formulas used to make a request. A case in point is the learner groups' employment of direct strategies. Although 
the Chinese low proficiency learner of English group and the Chinese high proficiency learner of English group prefer conventionally indirect strategies, they use more direct strategies than the native English group. The overuse of direct strategies by the learner groups especially the Chinese low proficiency learner of English group reflects influence from Chinese. As for direct semantic formulas, imperatives and want statements are preferred by the learner groups in situations with small imposition between participants of equal status, which is similar to the native Chinese group, for example, 请收拾你昨晚弄得残局。/please clean up the mess you made last night. When imperatives are used to make a request to a high-status requestee, internal modifiers will be used in the form of conditional + politeness marker+head act., for instance, If you don't have time now, Please fix the computer for me tomorrow. In Chinese, "politeness marker "qing'+imperative" or "imperative+ 'ba" is quite common in making a request. For example, 您请关机。/please turn off your mobile phone. 请把房间打扫一下吧。/Please clean your room. These are typical examples of Chinese requests: Chinese learners may rely more on these semantic formulas at the beginning stage of English learning in making a request. But with the increase of learners' English L2 proficiency and with the decrease of the use of imperative, the influence from Chinese seems to decrease as well.

As for external modifiers, all the learner groups show similar tendency with the native Chinese group and deviance from the native English group in frequency of apology, which is probably a result of influence from Chinese. In China, people tend to make apologies to especially higher-status or older people when they fail to fulfill an action which they think they should and the apology is followed by an offer of repair. For example, 非常抱歉, 王老师, 您说得太快了。您能不能说慢点。我保证会听明白的。/ I am very sorry, Mr.Wang. You speak too fast.Could you speak slower? I promise I can follow you. The reason for the high proficiency learners to employ the largest number of apologies might be that they know better than the low proficiency learners how to make a request in what they think the most polite way. English native speakers, by contrast, justify their requests by providing explicit reasons.

\subsection{Relationships between Requestive Semantic Formulas and L2 Proficiency}

Of the five request strategies, conventionally indirect strategies are strongly preferred by the learner groups as well as the native English group and the native Chinese group while indirect strategies are least frequently used. The employment of direct strategies, which are most frequently used by the Chinese low proficiency learner of English group, decreases with the increase of learners' L2 proficiency. The Chinese high proficiency learner of English group uses more conventionally indirect strategies than the Chinese low proficiency learner of English group. This indicates that the use of conventionally indirect strategies increases with the increase of learners' L2 proficiency.

With regard to internal modifiers, although the learner groups employ fewer syntactic downgraders in modifying their request than the native English group, the employment of syntactic downgraders increases with the increase of learners' L2 proficiency.

The Chinese high proficiency learner of English group employs fewer lexical/phrasal downgraders than the Chinese lower proficiency learner of English group, which shows that the use of lexical/phrasal downgraders decreases with the increase of learners' L2 proficiency. Although the Chinese high proficiency learner of English group outperforms the Chinese low proficiency learner of English group, it has much difficulty in employing a wide range of internal modifiers compared with the native English group.

As for external modifiers, the learner groups employ similar types of external modifiers as the native English group and the native Chinese group. Of the external modifiers, grounder and gratitude are favoured by all the groups, followed by offer, apology, promise, preparator in the decreasing order. No clear relationship is found between external modifiers and L2 proficiency.

\section{Conclusion}

This paper has studied how L1 pragmatic transfer works on the requestive behaviour of learners at different L2 proficiency levels. Complicated relationships have been found between L1 pragmatic transfer and L2 proficiency, and it is impossible to say whether L1 pragmatic transfer increases or decreases with L2 proficiency. There are cases in which L1 pragmatic transfer decreases with the increase of L2 proficiency such as the learners' use of direct strategies, lexical and phrasal downgraders, imperatives and grounder, and cases in which no clear relationship is found between L1 pragmatic transfer and L2 proficiency in terms of the other request strategies, internal modifiers and external modifiers. Therefore these results provide partial support to negative correlation hypothesis - high proficiency L2 learners are less likely to transfer their native language pragmatic norms since they have enough control over L2.

Since several factors have been identified to have an influence on the process of L1 pragmatic transfer, more empirical investigations are needed to investigate conditions under which L1 pragmatic transfer occurs. What is more, how L1 pragmatic transfer interacts with such factors as instruction and L2 input needs further investigation. 


\section{References}

Aijmer K. (1996). Conversational routines in English: convention and creativity. New York: Addison Wesley longman Ltd.

Blum-Kulka. (1982). Learning how to say what you mean in a second language. A study of speech act performance of learners of Hebrew as a second language. Applied linguistics, 3, 29-59. http://dx.doi.org/10.1093/applin/3.1.29

Blum-Kulka, S., House, J., \& Kasper, G. (Eds.). (1989). Cross-cultural pragmatics: Requests and apologies. Norwood, NJ: Ablex.

Kasper G. (1992). Pragmatic transfer. Second language research, 8(3), 203-231. http://dx.doi.org/10.1177/026765839200800303

Maeshiba N., yoshinaga, N., Kasper, G., \& Ross. (1996). Transfer and proficiency in interlanguage apologizing. In S. Gass, \& J. Neu (Eds.), Speech acts across cultures. Berlin: Mouton de Gruyter. pp. 155-187

Olshtain E., \& A. Co hen. (1989). Speech act behavior across languages. In H. W. Dechert, \& M. Raupach ( Eds. ), Transfer in language production. Norwood, NJ: Ablex.

Scarella R. (1983). Discourse accent in second language performance. In S. Gass, \& L. Seliker(Eds.), Language transfer in language learning, 306-326. Rowley, MA: Newbury House.ijmer.

Scarella R., \& Brunak, J. On Speaking politely in a second language. International Journal of the Sociology of Language, 27, 59-75

Takahashi S. (1996). Pragmatic transferability. Studies in Second Language Acquisition, 18

Takahashi T., \& L. Beebe. (1987). The development of pragmatic competence by Japanese learners of English. JALT Journal, 8

Troberg, A. (1987). Apology strategies in natives/non-natives. Journal of Pragmatics 11, 147-167. http://dx.doi.org/10.1016/0378-2166(87)90193-7

\section{Bio Data}

Jiemin $\mathrm{Bu}$ received his $\mathrm{M}$. A degree in English language and literature from Shanghai International Studies University in Shanghai, China. He is currently an associate professor of English in the foreign languages school, Zhejiang Guangsha College of Applied Construction, Zhejiang, China. He has been doing research in the field of linguistics, applied linguistics and pragmatics. He has published more than 20 papers in academic journals. His current research focuses on interlanguage pragmatics of Chinese learners of English.

Table 1. The Coding Scheme of Request Strategies

\begin{tabular}{|l|l|l|}
\hline Level of Directness & Strategy Types & Examples \\
\hline \multirow{5}{*}{ Direct } & Imperatives & Turn off your mobile phone. \\
\cline { 2 - 3 } & Want Statements & I want you to turn down music. \\
\cline { 2 - 3 } Performatives & $\begin{array}{l}\text { I am asking you not to block my } \\
\text { view. }\end{array}$ \\
\cline { 2 - 3 } & Hedged Performatives & $\begin{array}{l}\text { I would like to ask you to clean } \\
\text { the room. }\end{array}$ \\
\cline { 2 - 3 } & Obligation Statements & You must/ have to speak slowly \\
\hline Let's clean the room.
\end{tabular}


Table 2. Internal Modifiers of Requests

\begin{tabular}{|l|l|l|}
\hline Internal Modifications & Types & Examples \\
\hline Syntactic Downgraders & Interrogative & $\begin{array}{l}\text { Would/Could you do the cleaning } \\
\text { up? }\end{array}$ \\
\cline { 2 - 3 } & Negation & $\begin{array}{l}\text { I wonder if you wouldn't mind } \\
\text { saying it again. }\end{array}$ \\
\cline { 2 - 3 } & Past Tense & $\begin{array}{l}\text { I wanted to ask you to fix my } \\
\text { computer. }\end{array}$ \\
\cline { 2 - 3 } $\begin{array}{l}\text { Lexical and } \\
\text { Downgraders }\end{array}$ & Conditional Clause & $\begin{array}{l}\text { I would appreciate if you give me a } \\
\text { job interview. }\end{array}$ \\
\hline \multirow{3}{*}{ Upgraders } & Hedge & $\begin{array}{l}\text { I'd kind of like you to turn down } \\
\text { music. }\end{array}$ \\
\cline { 2 - 3 } & Subjectivizer & $\begin{array}{l}\text { I wonder if you can show me that } \\
\text { suit. }\end{array}$ \\
\cline { 2 - 3 } & Appealer & Let's clean the room, okay? \\
\hline & Lexical Intensifiers & I beg you to turn down music. \\
\cline { 2 - 2 } & Time Intensifiers & Please bring two towels at once. \\
\hline
\end{tabular}

Table 3. External Modifiers of Requests

\begin{tabular}{|l|l|}
\hline External Modification & Examples \\
\hline Preparator & Do you have time this Sunday? \\
\hline Grounder & My computer is out of order. Could you fix it for me ? \\
\hline Apology & I am sorry that I block your view \\
\hline Gratitude & Thank you \\
\hline Offer & I have two towels for you. \\
\hline Disarmer & I am sorry to disturb you. \\
\hline Promise of Future Action/Reward & $\begin{array}{l}\text { I promise I'll arrange a job interview for you as soon } \\
\text { as possible. }\end{array}$ \\
\hline Imposition Minimizer & We will bring you towels for a just while. \\
\hline Moralizing & We should keep our room clean and tidy \\
\hline Sweetener & You have beautiful suits. \\
\hline Empathy & I think you are too tired to clean it up. \\
\hline Confirmation & I hope you can bring your computer tomorrow. \\
\hline Emphasis of Importance & Please clean it up. Don't forget. \\
\hline Persuasion & The music is interesting. You will like it. \\
\hline Asking for Feedback & If you want to give me a job interview, please call me. \\
\hline Emphasis of Consideration & Please consider it carefully. \\
\hline Wishes & Have a good luck! \\
\hline &
\end{tabular}

Table 4. Frequencies and Percentages of Each Type of Request Strategies

\begin{tabular}{|l|l|l|l|l|}
\hline Strategy types & $\begin{array}{l}\text { Chinese low } \\
\text { proficiency } \\
\text { learner of } \\
\text { English Group }\end{array}$ & $\begin{array}{l}\text { Chinese high } \\
\text { proficiency } \\
\text { learner of } \\
\text { English Group }\end{array}$ & $\begin{array}{l}\text { Native English } \\
\text { Group }\end{array}$ & $\begin{array}{l}\text { Native } \\
\text { Chinese Group }\end{array}$ \\
\hline Direct & $40(40 \%)$ & $23(23 \%)$ & $15(15 \%)$ & $27(27 \%)$ \\
\hline $\begin{array}{l}\text { Conventionally } \\
\text { Indirect }\end{array}$ & $46(46 \%)$ & $68(68 \%)$ & $72(72 \%)$ & $60(60 \%)$ \\
\hline $\begin{array}{l}\text { Non-conventionally } \\
\text { Indirect }\end{array}$ & $8(8) \%$ & $6(7 \%)$ & $8(8 \%)$ & $9(9 \%)$ \\
\hline Indirect (Hints) & $1(1 \%)$ & $1(1 \%)$ & $2(2 \%)$ & $1(3 \%)$ \\
\hline Opting Out & $5(5) \%$ & $2(2 \%)$ & $3(3 \%)$ & $3(1 \%)$ \\
\hline Total & $100(100) \%$ & $100(100 \%)$ & $100(100 \%)$ & $100(100 \%)$ \\
\hline
\end{tabular}

$X^{2=} 94.863 \quad d f=12 \quad P=.000$ 
Table 5. Frequencies and Percentages of Each Sub-type of Request Strategies

\begin{tabular}{|l|l|l|l|l|l|}
\hline Strategy types & Sub-Type & $\begin{array}{l}\text { Chinese low } \\
\text { proficiency } \\
\text { learner of } \\
\text { English Group }\end{array}$ & $\begin{array}{l}\text { Chinese high } \\
\text { proficiency } \\
\text { learner } \\
\text { English Group }\end{array}$ & $\begin{array}{l}\text { Native } \\
\text { English } \\
\text { Group }\end{array}$ & $\begin{array}{l}\text { Native } \\
\text { Chinese } \\
\text { Group }\end{array}$ \\
\hline Direct & Imperatives & $25(25 \%)$ & $12(12 \%)$ & $8(8 \%)$ & $26(26 \%)$ \\
\cline { 2 - 7 } & $\begin{array}{l}\text { Want } \\
\text { Statements }\end{array}$ & $10(10 \%)$ & $7(7 \%)$ & $4(4 \%)$ & $1(1 \%)$ \\
\cline { 2 - 7 } & Performatives & $3(3 \%)$ & $2(2 \%)$ & $1(1 \%)$ & $0(0 \%)$ \\
\cline { 2 - 7 } & $\begin{array}{l}\text { Hedged } \\
\text { Performatives }\end{array}$ & $1(1 \%)$ & $1(1 \%)$ & $1(10 \%)$ & $0(0 \%)$ \\
\cline { 2 - 7 } & $\begin{array}{l}\text { Obligation } \\
\text { Statements }\end{array}$ & $1(1 \%)$ & $1(1 \%)$ & $1(1 \%)$ & $0(0 \%)$ \\
\hline Conventionally Indirect & $\begin{array}{l}\text { Suggestory } \\
\text { Formulas }\end{array}$ & $11(11 \%)$ & $13(13 \%)$ & $9(9 \%)$ & $55(55 \%)$ \\
\cline { 2 - 7 } & $\begin{array}{l}\text { Query } \\
\text { Preparatory }\end{array}$ & $35(35 \%)$ & $55(55 \%)$ & $63(63 \%)$ & $5(5 \%)$ \\
\hline $\begin{array}{l}\text { Non-conventionally } \\
\text { Indirect }\end{array}$ & $8(8) \%$ & $6(7 \%)$ & $8(8 \%)$ & $9(9 \%)$ \\
\hline Indirect (Hints) & & $1(1 \%)$ & $1(1 \%)$ & $2(2 \%)$ & $1(3 \%)$ \\
\hline Opting Out & $5(5) \%$ & $2(2 \%)$ & $3(3 \%)$ & $3(1 \%)$ \\
\hline \begin{tabular}{l} 
Total \\
\hline
\end{tabular} & $100(100) \%$ & $100(100 \%)$ & $100(100 \%)$ & $\begin{array}{l}100(100) \\
\%)\end{array}$ \\
\hline
\end{tabular}

$X^{2=} 94.863 \quad d f=12 \quad P=.000$

Table 6. Frequencies and Percentages of Internal Modifiers

\begin{tabular}{|c|c|c|c|c|}
\hline $\begin{array}{l}\text { Internal } \\
\text { Modifications }\end{array}$ & $\begin{array}{l}\text { Chinese low } \\
\text { proficiency } \\
\text { learner of } \\
\text { English Group } \\
\end{array}$ & $\begin{array}{l}\text { Chinese high } \\
\text { proficiency } \\
\text { learner of } \\
\text { English Group }\end{array}$ & $\begin{array}{l}\text { Native } \\
\text { English } \\
\text { Group }\end{array}$ & $\begin{array}{l}\text { Native } \\
\text { Chinese } \\
\text { Group }\end{array}$ \\
\hline $\begin{array}{l}\text { Syntactic } \\
\text { Downgraders }\end{array}$ & $25(25 \%)$ & $55(55 \%)$ & $69(68 \%)$ & $31(31 \%)$ \\
\hline $\begin{array}{l}\text { Lexical and } \\
\text { Phrasal } \\
\text { Downgraders }\end{array}$ & $72(72 \%)$ & $43(43 \%)$ & $27(27 \%)$ & $65(65 \%)$ \\
\hline Upgraders & $3(3) \%$ & $2(2 \%)$ & $4(4 \%)$ & $4(4 \%)$ \\
\hline Total & $100(100) \%$ & $100(100 \%)$ & $100(100 \%)$ & $100(100 \%)$ \\
\hline
\end{tabular}


Table 7. Frequencies and Percentages of Each Type of Internal Modifiers

\begin{tabular}{|c|c|c|c|c|c|}
\hline $\begin{array}{l}\text { Internal } \\
\text { Modifications }\end{array}$ & Types & $\begin{array}{l}\text { Chinese low } \\
\text { proficiency } \\
\text { learner of } \\
\text { English Group }\end{array}$ & $\begin{array}{l}\text { Chinese high } \\
\text { proficiency } \\
\text { learner of English } \\
\text { Group }\end{array}$ & $\begin{array}{l}\text { Native } \\
\text { English } \\
\text { Group }\end{array}$ & $\begin{array}{l}\text { Native } \\
\text { Chinese } \\
\text { Group }\end{array}$ \\
\hline \multicolumn{6}{|l|}{$\begin{array}{l}\text { Syntactic } \\
\text { Downgraders }\end{array}$} \\
\hline & Negation & $1(1 \%)$ & $0(0 \%)$ & $0(0 \%)$ & $22(22 \%)$ \\
\hline & Past Tense & $22(22 \%)$ & $50(50 \%)$ & $46(46 \%)$ & $0(0 \%)$ \\
\hline & $\begin{array}{l}\text { Conditional } \\
\text { Clause }\end{array}$ & $2(2 \%)$ & $5(5 \%)$ & $23(23 \%)$ & $9(9 \%)$ \\
\hline \multicolumn{6}{|c|}{ Lexical and Phrasal Downgraders } \\
\hline & Hedge & $32(32 \%)$ & $17(17 \%)$ & $18(18 \%)$ & $30(30 \%)$ \\
\hline & Subjectivizer & $27(27 \%)$ & $16(16 \%)$ & $8(8 \%)$ & $17(17 \%)$ \\
\hline & Appealer & $13(13 \%)$ & $10(10 \%)$ & $1(1 \%)$ & $18(18 \%)$ \\
\hline \multicolumn{6}{|l|}{ Upgraders } \\
\hline & $\begin{array}{l}\text { Lexical } \\
\text { Intensifiers }\end{array}$ & $1(1 \%)$ & $1(1 \%)$ & $3(3 \%)$ & $1(1 \%)$ \\
\hline & $\begin{array}{l}\text { Time } \\
\text { Intensifiers }\end{array}$ & $2(2 \%)$ & $1(1 \%)$ & $1(1 \%)$ & $3(3 \%)$ \\
\hline Total & & $100(100) \%$ & $100(100 \%)$ & $100(100 \%)$ & $100(100 \%)$ \\
\hline
\end{tabular}

Table 8. Frequencies and Percentages of External Modifiers

\begin{tabular}{|l|l|l|l|l|}
\hline $\begin{array}{l}\text { External } \\
\text { Modifications }\end{array}$ & $\begin{array}{l}\text { Chinese low } \\
\text { proficiency learner } \\
\text { of English Group }\end{array}$ & $\begin{array}{l}\text { Chinese righ } \\
\text { proficiency learner } \\
\text { of English Group }\end{array}$ & $\begin{array}{l}\text { Native } \\
\text { English } \\
\text { Group }\end{array}$ & $\begin{array}{l}\text { Native } \\
\text { Chinese } \\
\text { Group }\end{array}$ \\
\hline Preparator & $2(2 \%)$ & $4(4 \%)$ & $2(2 \%)$ & $2(2 \%)$ \\
\hline Grounder & $51(51 \%)$ & $43(43 \%)$ & $36(36 \%)$ & $41(41 \%)$ \\
\hline Apology & $6(6 \%)$ & $7(7 \%)$ & $3(3 \%)$ & $5(5 \%)$ \\
\hline Gratitude & $21(21 \%)$ & $21(21 \%)$ & $28(28 \%)$ & $20(20 \%)$ \\
\hline Offer & $10(10 \%)$ & $7(7 \%)$ & $7(7 \%)$ & $7(7 \%)$ \\
\hline $\begin{array}{l}\text { Promise of Future } \\
\text { Action/Reward }\end{array}$ & $4(4 \%)$ & $4(4 \%)$ & $3(3 \%)$ & $4(4 \%)$ \\
\hline Others & $6(6 \%)$ & $14(14 \%)$ & $21(21 \%)$ & $21(21 \%)$ \\
\hline Total & $100(100 \%)$ & $100(100 \%)$ & $100(100 \%)$ & $100(100 \%)$ \\
\hline
\end{tabular}

\section{Appendix 1}

Discourse Completion Test Questionnaire for the Native English Group and the Chinese Learner of English Groups

Name___ Gender____ Age ____ Grade ____ Specialization

You have been explained the purpose of this research and invited to participate in completing this questionnaire as part of the data collection procedure. Your completion of this questionnaire will help to ensure the success of the research and is therefore highly appreciated.

Please read the instruction and the given situations carefully and write your answers in English in the space provided under each situation. You should understand the requirements completely. Before you start, you are encouraged to ask questions if you find something you do not understand. It is important that you should complete this questionnaire according to your own ideas.

Thank you for your assistance. 
Instruction: Please read the following situations. After each situation please write what you would say in the situation in a normal conversation.

Situation 1: You are studying in the room and you hear loud music coming from your classmate's room. You ask him to turn down music. What would you say?

You:

Situation 2: You are shopping in a department store. You see a beautiful suit and want the salesperson to show you the suit. You ask the salesperson to show you the suit. What would you say?

You:

Situation 3: You are discussing your assignment with your teacher. Your teacher speaks very fast, you do not follow what he is saying, and so you ask your teacher to say it again. What would you say?

You:

Situation 4: Your computer is out of order. Your teacher is very skillful in fixing computer. You know that he has been busy recently, but you still want to ask him to fix your computer. What would you say?

You:

Situation 5: You are a teacher. In class, the mobile phone of one of your student rings. You ask your student to turn off his mobile phone. What would you say?

You:

Situation 6: You are watching a basketball game. A student you don't know comes and stands in just front of you blocking your view. You ask the students not to block your view. What would you say?

You:

Situation 7: You are applying for a new job in a company and want to make an appointment for an interview. You know the manager is very busy, but you still want to ask if he can give you an interview. What would you say?

You:

Situation 8: You are looking for the nearest post office in the street. You meet a stranger. You ask him how to go to the nearest post office. What would you say?

You:

Situation 9: You find your roommate Jack has left your room in a mess. You ask him to clean it up. What would you say?

You:

Situation 10: You are in a hotel and find there is no towel. You call to the front desk and ask them to bring towels. What would you say?

You:

\section{Appendix 2}

\section{汉语母语组语篇完形调查问卷}

姓名 性别 年龄 年级 专业 
已经向您解释了本研究的目的, 并邀请您参加问卷调查, 这个问卷调查是本研究数据收集程序的一部分。您 所填写的问卷将有助于确保本研究能够成功的进行。非常感谢您的参与。

请仔细阅读说明和情景。在空白处用中文填写您的回答。您应该了解问卷填写的要求。如果您有问题，在问 卷填写之前, 我们鼓励您提问以澄清问卷填写中您不明白的地方。您应该根据自己的观点完成这个调查问卷。 感谢您的协助。

说明：请阅读以下的情景。在每个情景后写出在一个正常的对话情境中您会说出的话语。

情景1: 您正在房间里学习您的功课, 听到从您的同学的房间里传来嘈杂的音乐。您请求他把音乐关小一点。 您会说什么?

您:

情景2: 您正在百货公司购物, 看见一套漂亮的西装, 并希望营业员能够把这套西装拿给您看。您请求营业 员把这套西装拿给您看。您会说什么?

您:

情景3: 您正在和老师讨论作业。您的老师说话非常快, 您没有听懂老师在说什么。您请求老师再说一遍。 您会说什么?

您:

情景4: 您的计算机坏了。您的一位老师非常擅长修理计算机。您知道他最近很忙。您还是要请求他修理您 的计算机。您会说什么?

您:

情景5: 您是一名教师。在课堂上, 您的一位学生的手机响了。您请求这位学生关掉他的手机。您会说什么? 您:

情景6: 您正在观看一场篮球比赛。一个您不认识的学生走过来站在您的前面, 挡住了您的视线。您请求这 位学生不要挡住您的视线。您会说什么?

您:

情景7: 您正在向一家公司申请一份新的工作, 并希望面试预约。您知道经理非常忙, 但您还是想请求他是 否能给您面试。您会说什么?

您:

情景8：您正在街上寻找一个最近的邮局。您遇见一个陌生人。您问他怎么去这个邮局。您会说什么? 您

情景9: 您发现您的室友小王把房间搞得一片混乱。您请求他去清理。您会说什么? 您

情景10: 您正在一家旅馆, 发现没有毛巾。您打电话给前台, 请求他们给您送毛巾。您会说什么? 您: 